\title{
Indicators of Website Features in the User Experience of E- Tourism Search and Metasearch Engines
}

\section{Trinidad Domínguez Vila ${ }^{1}$, Elisa Alén González ${ }^{2}$, Noelia Araújo Vila ${ }^{3}$ and Jose Antonio Fraiz Brea ${ }^{4}$}

\footnotetext{
1 University of Vigo, Faculty of Business Sciences and Tourism, Ourense, Spain, trinidad@uvigo.es

${ }^{2}$ University of Vigo, Faculty of Business Sciences and Tourism, Ourense, Spain, alen@uvigo.es

${ }^{3}$ University of Vigo, Faculty of Business Sciences and Tourism, Ourense, Spain, naraujo@uvigo.es

${ }^{4}$ University of Vigo, Faculty of Business Sciences and Tourism, Ourense, Spain, jafraiz@uvigo.es
}

Received 30 May 2019; received in revised form 23 September 2019; accepted 10 December 2019

\begin{abstract}
The continuous growth of e-commerce, combined with new trends in the tourism sector, creates an imperative to conduct analyses and establish suitable models for improving the experience of users who seek tourism products online, using search and metasearch engines. However, few studies analyze web design variables and their impacts on the user experience. Therefore, the present study aims to investigate the influence of content, usability, functionality, and branding for determining user experiences with search engines and metasearch engines dedicated to tourism. The methodology used in this research followed a mixed approach to fulfill the proposed dual perspective, that is, to collect data from websites and evaluate the user experience. To determine the variables to be modeled, the authors use a General Additive Model. Main results reveal two determinant factors that enhance the user experience: usability and branding. With this foundation, this study proposes basic premises of the digital strategy that tourism platforms should follow. As implications for the tourism sector, suggest that e-commerce search and metasearch engines in the tourism industry should devote substantial efforts to implementing interactivity, memorability, personalization, privacy, and security.
\end{abstract}

Keywords: User experience, E-commerce, Tourism search and metasearch engines, GAM

Trinidad Domínguez Vila Elisa Alén González Nelia Araújo Vila José Antonio Fraiz Brea 


\section{Introduction}

Access to the use of the Internet produces changes throughout people's daily lives. In the economic sphere, online marketing and the growth of electronic commerce (e-commerce) have altered how business gets conducted, everywhere around the world. With this tool, companies have gained a new way to perform tasks, interact with users, and manage their business [112]. Specifically, in the tourism industry, e-commerce has gained substantial and still growing prominence. According to the European Union report [50] the second more common online purchases during year to the 2016 survey was travel and holiday accommodation (52\% of e-shoppers in the EU). In turn, e-commerce has had significant effects on how tourism goods and services are sold [5], [107], and its adoption and use in the tourism industry has created new opportunities to introduce innovative management practices. Moreover, e-commerce seems likely to continue to grow, due to its potential to reduce costs, enable global coverage, expand the customer base, and improve productivity [30]. From a demand perspective, the number of tourists who use the Internet to search for information and make online reservations provides clear evidence of the popularity of e-commerce among tourists [51], [83]. Some impacts of internet use on travel planning behaviours have been identified in different researches, and for instance, these users tend to spend more in the destination [21], [90] and they consider more destinations [22] compared to those who consult other information sources. Although, friends, family or colleagues and online sources are critical for travel inspiration with a total of $56 \%$ of users, $74 \%$ of leisure travellers and $77 \%$ of business travellers using internet as a planning source [69]. Social networking, video or photo sites are the most popular (83\%) along with the search engines with $61 \%$. Search engines are the most popular online planning source for $60 \%$ of travellers and the second most popular for $55 \%$ of business travellers. Clearly, users tend increasingly to booking online, representing $87 \%(70 \%$ do so via computer, $38 \%$ via smart phone and $17 \%$ via tablet) and $29 \%$ do so via phone call [69]. Phocuswright [107] estimated that the online travel sector to reach $\$ 540 \mathrm{bn}$ in 2017, up 8\% and with $\$ 38 \mathrm{bn}$ incremental growth, with a gross booking reached of $\$ 1.6$ trillion (include airline, hotel, car rental, rail, travel package and cruise), making it one of the largest and fastest growing sector in the world, where the online travel agencies (OTAs) are the key. E-commerce supports not only buying and selling but also a wide range of pre-purchase activities [58], such as searching for information about tourist activities or gathering recommendations [70]. In this context, research into online information searches [71] has expanded substantially, especially in the travel and tourism field [103]. In particular, a key question pertains to how best to ensure that users can locate correct and relevant travel and tourism information within the online tourism domain [140], spanning the online space that can be accessed from users' preferred Internet gateways, in the form of search and metasearch engines.

In particular, approximately $70 \%$ of online tourism consumers start their search before deciding where or how they want to travel [70]. These new consumer habits generate new action models. For example, tourism websites now provide means for tourism organizations to promote their products and communicate with actual or potential tourists [128]. These websites represent key sources of information for tourists before they arrive at their destination and during their trip too [32], [122], in which sense tourism websites increasingly function as marketing tools [85]. In this role, they promote offerings and provide an important distribution channel for domestic and international tourism [85]. The new intermediaries can be classified into three main groups: metasearch engines (e.g., Trivago that combines more than 260 search engines), search engines (e.g., Airbnb), and social channels (e.g., Facebook, Twitter Instagram) although this acts more as a search for information than an e-commerce channel [140]. The difference between search engines and metasearch engines is that the latter provide comparison functions, by searching across many engines and browsers, but they do not have their own database. Metasearch engines enable website users to search across several search engines and web directories simultaneously and help them find more results without requiring them to move through multiple search engines [63]. Their influence on tourist decisions is growing [69], such that $59 \%$ of tourists say that these engines are their preferred sources for travel ideas, information, and comparisons, mainly in relation to airlines, hotels, and car rentals [69]. Despite this growing importance in practice, for both tourism [103] and marketing [125], specific insights about these technological tools in relation to tourism industries in different destinations and sectors remain lacking [142]. Therefore, the current study analyzes how the content, usability, functionality, and branding of search engines and metasearch engines affect the user experience in e-commerce tourism. A literature review first establishes which attributes of web design are relevant to users' experience. The analysis of possible relationships then suggests ways to improve the benefits websites, reflecting the preferences and usage habits of online tourism users.

As its main contribution, this research tries to establish the principal user preference factors of the tourism e-commerce websites, and their attributes, using a mixed approach to study tourism websites from a dual perspective on utilitarian quality (website) and hedonic quality (user). In turn, it identifies the tendencies followed by destination management organizations (DMOs) with their websites and whether they satisfy demands from users and provide good experiences.

Many studies consider e-commerce and its related variables, but little research assesses variables related to website design or their impact on user experiences [54, 98, 102], being this one the biggest contribution of this study. Thus, the analysis of the influence of content, usability, functionality, and branding on user experiences with search engines and metasearch engines for e-commerce tourism is the novelty. Instead, most studies focus on web quality measures and quality assessments of website structures [40]. It may be useful for managers of metasearch and search engines to unravel the key features of a company's digital strategy, then use them to generate specific actions to maintain or improve it. 
To do this, the present study first performs a theoretical review of the terms linked to e-commerce in tourism and the user preference for e-tourism websites. The methodology followed in the empirical part of the work is explained, a mixed approach to fulfil the proposed dual perspective, that is, to collect data from websites (offer perspective functional quality) and evaluate the user experience (demand perspective - hedonic quality). Results determine the attributes and categories that influence the key factors for e-tourism websites. The main conclusions obtained are shown, among them that the consumers' behaviour is very similar and does not distinguish them. Finally, the limitations of the study and future research are shown.

\section{Literature Review}

Studies of e-commerce in tourism mainly seek to analyze users' behavior, such as online travel planning [52], [76], the frequency of uses of e-tourism and socio-economic factors [131], online hotel bookings [7], [37], and intentions to repurchase [146]. A few other studies evaluate the different processes and functionalities available on tourism webpages. Hernández et al. [62] review the main factors to take into account in an e-commerce website, and Li and Buhalis [86] segment the information by identifying factors that influence tourists' online purchases. Some researchers focus on specific elements of tourism web pages too, such as content [117], performance through specific features [16], [44], accessibility and quality of content and interfaces [5], [40], and usability [110]. These studies take a design perspective.

Before moving forward, it is necessary to define key concepts that will be used throughout this work as e-tourism, ecommerce or e-tourism website. E-tourism means the analysis, design, implementation and application of information and communication technology and e-commerce solutions in the travel and tourism industry; as well as the analysis of the respective economic processes and market structures and customer relationship management [143]. The term e-tourism should include ecommerce feature such as online purchasing, product information, personalization, transaction term and condition, product review, and links [132] or the way tourism organizations conduct their business and, in particular, how distribute their tourism products in the online marketplace [133].

Web design is a key factor for ensuring a good interface that can satisfy consumer needs, and for this reason, the companies must ensure good designs to survive in competitive online markets [54]. Web designs can lead to higher levels of customer satisfaction [77], [78] and thereby increase online purchase intentions [130]. According to this view, a product should facilitate do-goals, such that it offers utilitarian quality. The user experience then is synonymous with usability and user-centered design [139]. However, this perspective is insufficient, because it excludes be-goals that users pursue during web interactions, which require hedonic quality, as can be achieved when the consumer is able to find and purchase a particular good or service easily [61]. Therefore, research also needs to incorporate experiential factors.

According to Muhtaseb et al. [98], who study user preferences for e-tourism websites, website design informs enduser experiences; in particular, this experience depends fundamentally on four factors: (1) actual content of the site (text, multimedia, images), its structure, and its information architecture; (2) usability, or the general ease of use of all site components and features; (3) functionality, which includes technical and behind-the-scenes processes and applications [111]; and (4) branding, or aesthetic and design-related items available on a website. The scope of these factors is consistent with other proposals by different authors in terms of quality and intentions to use the website, as Table 1 shows. The current study relies on users to evaluate the identified factors subjectively, with the notion that the user experience includes all aspects of product usability and desirability from the user's own perspective [129].

Table 1: User preference for e-tourism websites in prior research

\begin{tabular}{|l|l|}
\hline User preferences & Factors with similar meaning \\
\hline $\begin{array}{l}\text { Contents: all the material transmitted and made avaible on } \\
\text { an e-tourism website [97] }\end{array}$ & $\begin{array}{l}\text { - Content, linkage, appearance [26], [120]. } \\
\text { - Easy to use [41], [89], [98], [136]. }\end{array}$ \\
\hline $\begin{array}{l}\text { Usability: a combination of efficiency and effectiveness, in } \\
\text { support of user goals and tasks [10]. }\end{array}$ & $\begin{array}{l}\text { - - Use [120]. } \\
\text { - Usefulness [41], [89], [136]. } \\
\text { - Usability [23], [49]. }\end{array}$ \\
\hline $\begin{array}{l}\text { Functionality: all the processes and behaviors foreseen in } \\
\text { the backend. }\end{array}$ & $\begin{array}{l}\text { - Structure [120]. } \\
\text { - Functionality [23]. }\end{array}$ \\
\hline $\begin{array}{l}\text { Branding: the intelligent, strategic and creative management } \\
\text { of all those distinguishing elements of a brand identity } \\
\text { (tangible or intangible) that contribute to construct a promise } \\
\text { and a distinctive, relevant, comprehensive and sustainable } \\
\text { brand experience over time [125]. }\end{array}$ & - Search and information. \\
\hline
\end{tabular}

A positive user experience is vital to commercial success. Bernardo et al. [17] assert that when travel agencies design e-commerce sites, they must recognize that customers want to achieve their goals, in terms of making an appropriate purchase, but also seek to enjoy the purchase experience. Companies therefore should study customers' web use 
behaviors and provide hedonic functionalities; once utilitarian quality is achieved; the hedonic dimension can differentiate a website. In this sense, and to overcome the limitations of previous research that focuses on either design or user perspectives, the current study proposes a mixed approach. Various factors have impacts on the user experience, and they can be evaluated both from a functional perspective, analyzing user preferences attributes and website categories (see Table 2), and from a hedonic perspective, using subjective evaluations of the factors that determine customer satisfaction.

Website content synthesizes various elements, including content, links, appearance, ease of use, entertainment value, reliability, and portability (see Table 1). This factor is critical, because customers use e-tourism websites as information sources. Therefore, they need to be designed to match end users' needs and expectations [67]. Lists of information about a product or destination are not effective in helping tourists plan their trips [43]. Moreover, website content can evoke product images and create a virtual consumer experience, which influences users' perceptions of the company or tourism destination [32]. This crucial element for website design thus can ease the user experience [41], [46], [75] [89], [105]. Several studies also highlight the importance of content in connection with various attitudinal and behavioral outcome variables [55]. For tourism websites, content is a main attribute that leads people to revisit [118] and increases their satisfaction [81] and purchase intentions [24]. A well-organized web page also appears less complex and more user friendly, which enhances the quality of the user experience [99]. Based on the previous findings in the e-tourism setting, is hypothesize that:

\section{H1: Website contents have a positive effect on the user experience of an e-tourism website.}

Usability is another key pillar [23], [40], [89], [136]. It reflects how easily a user interacts with a website and how easy the user interface feels. It appears equivalent to use, usefulness, or usability (see Table 1). Some evidence indicates a direct relationship between usability and user experience. Calero et al. [23] found that usability, at $47.8 \%$, is the mainly quality characteristic to use to classify web metrics. Vijayasarathy [135] similarly argues that usefulness and ease to use explain intentions to use e-commerce, because they reduce time in the process. Davidavičienè and Tolvaišas [40], studying the quality of e-commerce websites, acknowledge usability as a key element both before and during the purchase. Usability leads to more effective websites, which increase consumer loyalty [98] and improve conversion ratios (i.e., proportion of visitors to the website who actually make a purchase, relative to the total number of visitors). Usability makes it easier for users to determine how to achieve their consumption goals, especially when achieved through good web design, which influences users' affective states and evoke feelings of pleasure through its use [54]. Extending the previous findings, the following hypothesis can be posited:

\section{H2: Website usability have a positive effect on the user experience of an e-tourism website}

Although attributes that are part of functionality (i.e., access and functional design) are key elements of a positive user experience, functionality is not one of the most important determinants of user experiences with websites [23] and exhibits little significance in electronic service quality models [120], because it is something that users give as inherent to the website. Even if a lack of access or functional design, as manifested in poor development, prevents effective uses of the website, with direct and negative effects on the user's experience, users do not identify them as key elements, because are not perceived in the first instance. As Cunliffe [39] points out, poor website design could result in losses of 50 percent of potential sales, and a negative experience reduces the potential of repeating visits by 40 percent.

Some studies establish functionality as a determinant of the correct functioning of the website; the relevant attributes include multiple functions and their specified properties [3], [13], [83], [147] that satisfy some stated or implied needs [23]. Kaplanidou, Vogt and Morris [76] argue that functionality is not a direct predictor of intentions to travel, but they find an indirect influence through the perceived usefulness of the website. A successful website therefore holds customers' interest, encourages them to participate, and captures information about their preferences [20]. Travellers expect websites to be informative, interactive, and attractive [34], and in turn, functionality depends on the usefulness of the website for users [79]. Based on all of these researches, the next hypothesis is suggested:

\section{H3: Website functionality have a positive effect on the user experience of an e-tourism website.}

If Branding concept is used in the field of the e-commerce, refers to the process of transforming the website into a unique experience for the user [3], [120]. It gives a clear picture of your company through the information that is presented, the way it is presented, and the user experience of the site [36]. The brand of websites depends on all interactions between the company and the user in the online environment [134]. In the specific e-tourism field, the brand also offers a means for recognition, which provides a cognitive anchor that can reassure customers who face uncertainty [113]. Consumers might rely on trusted corporate or brand names, as a substitute for unavailable product information [87]. Branding becomes particularly relevant due to the nature of online shopping, which prevents customers from feeling or touching products before purchasing them [4]. Tourists who are familiar with a well-known brand might perceive their shopping experiences as better in this context. Therefore:

H4: Website branding have a positive effect on the user experience of an e-tourism website. 
With these predictions, this research empirically tests the relationship of the user experience in an e-tourism website with its content, usability, functionality, and branding. In addition, this research seeks to determine which attributes and categories influence these factors in e-tourism websites (see Table 2), to facilitate possible search strategies. Tourism information searches can be individual or collaborative activities [64]. Individual or internal searches for tourism information [73] involve mental process that support information acquisition, selection, judgment, and utilization. Users cannot process all information available, so they turn to strategies to find and select reliable information, using keyword searches, search engines, subject directories or browsing, as well as visiting known sites [64]. Positioning on the Internet is a determining factor, whether it relies on search engine marketing (SEM) or search engine optimization (SEO). Both processes aim to increase visibility, but whereas SEO refers to a process of getting traffic from the free, organic, editorial, or natural search results, SEM implies purchasing ads. Furthermore, SEO uses various strategic tactics to increase the amount of visitors to a website by ensuring a higher placement in the search results page of a search engine. In contrast, SEM is Internet marketing, and it involves researching, submitting, and positioning of a website within search engines to achieve maximum visibility and increase the share of paid and/or organic traffic referrals attained from search engines [114].

A collaborative tourism information process instead features information sharing, to plan trips before, during, and after the visit. Social media constitutes an important information source [140] with powerful impacts on tourists' decisionmaking process, because they can share information and travel experiences [35]. In online communities, users seek, synthesize, and disseminate information, which they can share using different channels, such as chat, voice, video, blogs, applications, or likes. Users searching for tourism information may collaborate for various purposes [8], such as gathering, verifying, and updating information. However, previous experiences, knowledge, and memories related to web searches and destinations strongly influence online tourism information searches [64].

In summary, users' search strategies reflect both technical and collaborative components, and keyword searches, search engines, subject directories, browsing the web, and visiting known sites are important for sharing information and experience about the trip with other travellers. For this reason, this study seeks to establish the attributes and categories that influence e-tourism websites users, to determinate the appropriate online strategy to follow.

\section{Methodology}

The methodology used in this research followed a mixed approach to fulfill the proposed dual perspective, that is, to collect data from websites (offer perspective - functional quality) and evaluate the user experience (demand perspective - hedonic quality). First of all, it was necessary to identify the dimensions or factors of the user preferences attributes for websites. These factors and attributes were established using a qualitative meta-analysis of the literature about the topic (they are listed in Table 2). Secondly, the study sample was determined following Xian et al. study [141]. A series of keywords combined with the top destinations selected by their earnings from international tourism, resulted in a series of internet website outputs that after a refinement consisted in 99 search and metasearch engines (appendix A). Using a content analysis, each website of the sample was rated on a 5-point Likert scale according to the number of criteria met in relation to the total listed for each factor of the user preference. Summarizing, the metaanalysis in the first phase selected eight more relevant tourist destinations in the world to be used for the search in combination with keywords. In the second, the six search keywords to be used in conjunction with the chosen destinations were selected. And finally, a combination of destinations and selected keywords, with total of 48 terms met all the criteria listed, which were search in the Google search engine.

On the other hand, to obtain data about hedonic quality, the research of Power [109] has been used, which asked each user to evaluate their personal experience with the online travel search and metasearch engines during the previous 12 months. All data is analysed used an exploratory factorial analysis to determine the attributes and categories that influence the key factors for e-tourism websites, completed with a General Additive Model (GAM) to try to relax the assumption of linearity between the dependent and independent.

\subsection{Dimensions}

To analyze the influence of content, usability, functionality, and branding on user experiences with search engines and metasearch engines for e-commerce tourism, this study defines the dimensions to be assessed in relation to each factor by starting with a qualitative meta-analysis [105] of success attributes for destination marketing websites. That meta-analysis reflects the findings of multiple studies pertaining to e-tourism [76], [95], [97], [121], [122]. A further extensive review includes research performed in other fields to help establish the most important attributes and categories for analyzing e-commerce websites. Considering the study focus on the tourism industry, specific variables related to the tourism business were also included. The different attributes identified for each factor are listed in Table 2. For example, the content factor includes four attributes: composition of contents, design and structure, learning, and navigation. Some categories can also be differentiated according to whether they refer explicitly to e-commerce, etourism, or both. Although the literature review has been profound and varied, as can be seen in the following table, there being no excessive empirical work that tests the attributes of each factor. There is a paradox that according to the author followed, the same attribute can be framed in different factors, and moreover when the definition of each one is not specific enough to limit its field of action. This is the reason why the authors, even justifying the establishment 
of each theoretical construct based on the reviews carried out, find that certain theoretical contradictions could occur but they are expected to be solved through the empirical analysis.

Table 2: User preference attributes for websites

\begin{tabular}{|c|c|c|c|c|}
\hline \multirow{2}{*}{$\begin{array}{l}\text { Website } \\
\text { structure } \\
\text { attributes }\end{array}$} & \multirow[b]{2}{*}{ Definitions } & \multicolumn{2}{|l|}{ Categories } & \multirow[t]{2}{*}{ Author } \\
\hline & & e-Tourism & e-Commerce & \\
\hline & \multicolumn{4}{|l|}{ CONTENT } \\
\hline $\begin{array}{l}\text { Composition of } \\
\text { contents }\end{array}$ & $\begin{array}{l}\text { The textual, visual, or aural content } \\
\text { encountered as part of the user } \\
\text { experience on websites }\end{array}$ & \multicolumn{2}{|c|}{$\begin{array}{l}\text { Organization, layout, heading and style, } \\
\text { readability, current and timely } \\
\text { information, complexity, informative } \\
\text { product page }\end{array}$} & $\begin{array}{l}\text { [14], [15], [24], [25], } \\
{[49],[55],[95],[98],} \\
\text { [104], [105], [120], } \\
{[144]}\end{array}$ \\
\hline $\begin{array}{l}\text { Design and } \\
\text { structure }\end{array}$ & $\begin{array}{l}\text { How the website is set up and the } \\
\text { individual subpages are linked }\end{array}$ & \multicolumn{2}{|c|}{$\begin{array}{l}\text { Website design, homepage, graphical } \\
\text { interface, page background, color } \\
\text { consistency, }\end{array}$} & $\begin{array}{l}\text { [14], [15], [24], [25], } \\
{[46],[54],[88],[95],} \\
{[98],[100],[104],[105],} \\
{[120],[144]}\end{array}$ \\
\hline Learning & $\begin{array}{l}\text { Ways to create processes to learn } \\
\text { and improve the customer } \\
\text { experience with the website }\end{array}$ & \multicolumn{2}{|c|}{$\begin{array}{l}\text { Familiarity, consistency, generalizability, } \\
\text { predictability, simplicity }\end{array}$} & $\begin{array}{l}\text { [14], [15], [24], [46], } \\
\text { [49], [88], [89], [94], } \\
{[98],[104],[105],[120],} \\
{[135]}\end{array}$ \\
\hline Navigation & $\begin{array}{l}\text { The possibility of movement from } \\
\text { one webpage to another page. }\end{array}$ & \multicolumn{2}{|c|}{$\begin{array}{l}\text { Know where they are, easily return, } \\
\text { search }\end{array}$} & $\begin{array}{l}\text { [15], [23], [24], [25], } \\
{[55],[88],[92],[93]} \\
{[94],[98],[105],[120]} \\
{[144]}\end{array}$ \\
\hline & \multicolumn{4}{|l|}{ USABILITY } \\
\hline $\begin{array}{l}\text { Interactivity } \\
\text { (real time, help) }\end{array}$ & $\begin{array}{l}\text { The dialog that occurs between a } \\
\text { customer and a computer program. }\end{array}$ & \multicolumn{2}{|c|}{$\begin{array}{l}\text { Computer-mediated, communication, } \\
\text { real-time communication, dialogue, } \\
\text { interactive decision aids, transaction- } \\
\text { related vs. non-transaction related } \\
\text { interactivity }\end{array}$} & $\begin{array}{l}\text { [15], [23], [24], [42], } \\
{[46],[88],[91],[94],} \\
{[98],[104],[105],[120],} \\
{[144]}\end{array}$ \\
\hline Memorability & $\begin{array}{l}\text { The ability to navigate and use a } \\
\text { website quickly and easily by the } \\
\text { user, each time. }\end{array}$ & \multicolumn{2}{|l|}{ Interface memorability } & [14], [98], [100], [105] \\
\hline $\begin{array}{l}\text { Purchase } \\
\text { management } \\
\text { method }\end{array}$ & $\begin{array}{l}\text { The way a buyer chooses to } \\
\text { compensate the seller for a good or } \\
\text { service, so the seller must manage } \\
\text { the formal process of planning, } \\
\text { implementation, evaluation, and } \\
\text { control of purchases }\end{array}$ & $\begin{array}{l}\text { Visa, Mastercard, } \\
\text { Maestro, Visa } \\
\text { Electron, American } \\
\text { Express, Paypal, } \\
\text { Company Card } \\
\\
\text { Bill, premium } \\
\text { service, possibility of } \\
\text { reimbursement }\end{array}$ & $\begin{array}{l}\text { Visa, } \\
\text { Mastercard, } \\
\text { Maestro, Visa } \\
\text { Electron, } \\
\text { American } \\
\text { Express, } \\
\text { Paypal, } \\
\text { Company Card } \\
\text { Offline, bill, } \\
\text { returns, return } \\
\text { costs, } \\
\text { administrative } \\
\text { costs, premium } \\
\text { service, } \\
\text { possibility of } \\
\text { reimbursement }\end{array}$ & $\begin{array}{l}\text { [15], [23], [24], [88], } \\
{[120]}\end{array}$ \\
\hline $\begin{array}{l}\text { Performance } \\
\text { and availability } \\
\text { (easy search) }\end{array}$ & $\begin{array}{l}\text { The online process by which the } \\
\text { customer pays for the results } \\
\text { obtained, that is, the extent to which } \\
\text { an application is operational, } \\
\text { functional, and usable for } \\
\text { completing or fulfilling a customer's } \\
\text { requirements. }\end{array}$ & \multicolumn{2}{|c|}{$\begin{array}{l}\text { Efficiency, product differentiation and } \\
\text { comparisons }\end{array}$} & $\begin{array}{l}\text { [14], [15], [23], [24], } \\
{[42],[46],[88],[94],} \\
{[98],[100],[104],[135],} \\
{[144]}\end{array}$ \\
\hline Personalization & $\begin{array}{l}\text { The process of tailoring pages to } \\
\text { individual users' characteristics or } \\
\text { preferences. }\end{array}$ & \multicolumn{2}{|c|}{$\begin{array}{l}\text { Recognizing visitors, customization of } \\
\text { content, tailoring, explicit and implicit } \\
\text { personalization }\end{array}$} & $\begin{array}{l}{[2],[25],[28],[66],[98],} \\
{[104],[105]}\end{array}$ \\
\hline $\begin{array}{l}\text { Privacy and } \\
\text { security }\end{array}$ & $\begin{array}{l}\text { Protection of all types of } \\
\text { information, in any form; assurances } \\
\text { that any personal information } \\
\text { collected and processed (used) also } \\
\text { is protected and destroyed legally } \\
\text { and fairly. }\end{array}$ & \multicolumn{2}{|c|}{$\begin{array}{l}\text { Personally, identifiable information, } \\
\text { transmission of transactional } \\
\text { information, lack of control, trust, } \\
\text { assurance sales }\end{array}$} & $\begin{array}{l}{[14],[15],[23],[24]} \\
{[88],[94],[98],[104]} \\
{[105],[120],[135]}\end{array}$ \\
\hline & \multicolumn{4}{|l|}{ FUNCTIONALITY } \\
\hline Access & $\begin{array}{l}\text { Opportunity to approach or enter a } \\
\text { website and surf it }\end{array}$ & \multicolumn{2}{|l|}{ Accessibility needs } & [59], [70], [105] \\
\hline
\end{tabular}

Trinidad Domínguez Vila Elisa Alén González Nelia Araújo Vila José Antonio Fraiz Brea 


\begin{tabular}{|c|c|c|c|c|}
\hline $\begin{array}{l}\text { Functional } \\
\text { design }\end{array}$ & $\begin{array}{l}\text { A paradigm to simplify the design } \\
\text { of hardware and software devices }\end{array}$ & \multicolumn{2}{|l|}{ Satisfactory design } & [70], [98], [105], [144] \\
\hline & \multicolumn{4}{|l|}{ BRANDING } \\
\hline Loyalty system & $\begin{array}{l}\text { Structured marketing strategies } \\
\text { designed by merchants to } \\
\text { encourage customers to continue to } \\
\text { shop at or use the services of } \\
\text { businesses associated with each } \\
\text { program }\end{array}$ & \multicolumn{2}{|c|}{$\begin{array}{l}\text { Mailing, chat, promotions, discount } \\
\text { bond, gift card, gift certificate, field } \\
\text { collection of questions and/or } \\
\text { suggestions }\end{array}$} & [1], [84] \\
\hline $\begin{array}{l}\text { Package } \\
\text { components }\end{array}$ & $\begin{array}{l}\text { A pre-arranged combination of at } \\
\text { least two tourist components } \\
\text { (accommodation, transport, other } \\
\text { tourist services), and sold or offered } \\
\text { for sale at an inclusive price, } \\
\text { covering a period of more than } 24 \\
\text { hours or including overnight } \\
\text { accommodation }\end{array}$ & $\begin{array}{l}\text { Flight, } \\
\text { accommodation, } \\
\text { flight+hotel, } \\
\text { flight+hotel+tour, } \\
\text { hotel+tour+holidays, } \\
\text { holidays, cruises, } \\
\text { tour, breaks, } \\
\text { destinations, cars, } \\
\text { coaches, trains, } \\
\text { apartments, leisure } \\
\text { activities }\end{array}$ & $\begin{array}{l}\text { Flight, } \\
\text { accommodatio } \\
\text { n, flight+hotel, } \\
\text { cruises, tour, } \\
\text { cars, coaches, } \\
\text { trains, } \\
\text { apartments }\end{array}$ & $\begin{array}{l}\text { [9], [37], [51], [74], } \\
\text { [127], }\end{array}$ \\
\hline $\begin{array}{l}\text { Product } \\
\text { browser }\end{array}$ & $\begin{array}{l}\text { Search functionality that allows } \\
\text { users to select different options from } \\
\text { a database }\end{array}$ & \multicolumn{2}{|c|}{$\begin{array}{l}\text { Filtering by destination, product, } \\
\text { category, use browsers, use filters, use } \\
\text { some languages }\end{array}$} & $\begin{array}{l}\text { [9], [37], [52], [82], } \\
{[101]}\end{array}$ \\
\hline Product type & Grouping of similar kinds of services & $\begin{array}{l}\text { Accommodation, } \\
\text { journey, leisure, } \\
\text { package holidays }\end{array}$ & $\begin{array}{l}\text { Accommodatio } \\
\mathrm{n}, \text { package } \\
\text { holidays }\end{array}$ & $\begin{array}{l}\text { [9], [37], [52], [65], } \\
\text { [127] }\end{array}$ \\
\hline Social media & $\begin{array}{l}\text { Collective of online communications } \\
\text { channels dedicated to community- } \\
\text { based input, interaction, content- } \\
\text { sharing, and collaboration }\end{array}$ & \multicolumn{2}{|c|}{$\begin{array}{l}\text { Social networks, blogs, collaborative } \\
\text { projects, virtual, content communities, } \\
\text { applications }\end{array}$} & [33], [68], [72] \\
\hline
\end{tabular}

The attributes in Table 2 build the factors for the analytical model, measured using the items listed in each sub-category. Similar studies focused on the attributes of the products on offer serve as points of reference [37], [48]. An assessment gauged whether each category existed, rated on a 5-point Likert scale according to the number of criteria met in relation to the total listed for each factor, following a percentage criterion [48]. Therefore, each point of the scale represents the percentage of compliance in the analyzed category. These data reflect utilitarian quality, as suggested by prior research [109].

\subsection{Sample}

Following Xiang et al. [141], the method mimics travellers' use of a search engine to search for destination-related information, to determine what factors compose utilitarian quality. The keywords were entered into a Google search, which in combination with the selected destinations, resulted in the sample used for this study. DeVellis [45] identifies two critical considerations that determine the validity of this sampling method. The predefined keywords must represent the object to be studied in a coherent way, and they must offer the greatest possible coverage. This study used a list of 90 words grouped into six categories [95], [136], [141]: tourism, accommodation, trip, travel, transport, and booking. The use of Google to search for data is justified by its ranking as the search engine with the highest market share [116].

Next, the selection of destinations to be analyzed was based on income earned from international tourism, using data from the UNWTO [138], namely and in order of importance: United States, Spain, China, France, Italy, United Kingdom, Germany, and Thailand. These countries accrued international tourism revenues in 2018 worth $\$ 567.7$ million, representing $42.3 \%$ of the world total.

Finally, the destinations and keywords were combined to create 48 search terms that met all the necessary criteria. To refine the sample, the final listing of websites excluded those that offered a single product or service, such as airline websites and hotels. As a result, the sample consists of 99 search engines and metasearch engine tourism websites that conducted e-commerce (Appendix B). The database was compiled between March and June 2016.

To obtain data about hedonic quality, this study followed Power [109] which asked each user to evaluate their personal experience with the online travel agency, including search and metasearch engines. Seven user experience factors determine customer satisfaction with the competitive pricing, usefulness of information, and availability of booking options, which are the top three in order of importance. This ranking reflects the responses of more than 2,600 consumers who made purchases on travel websites in the previous 12 months. The survey was sent to consumers whose names were randomly selected from data maintained by independent companies, fielded from March 11-31, 2016. 


\section{Data Analysis and Results}

An exploratory factorial analysis sought to determine the attributes and categories that influence the key factors for etourism websites. An initial reliability and validity analysis produced the results in Table 3 . All the Cronbach's alpha coefficients are above the recommended 0.80 level [11], [19]. The test of convergent validity confirmed that the different item loadings are equal to or above the recommended cut-off level of 0.60 [30]. Four attributes had to be excluded, due to their low representativeness or their failure to meet the validity and reliability parameters: loyalty system, social media, payment and management method, and performance. The four factors are distinct, with variance explained values higher than $55 \%$ in all cases. The composite reliability (CR) values [56] are very good; the average variance extracted (AVE) also exhibits values of 0.5 or higher, and the recommended minimum values are 0.5 [11]. Therefore, the exploratory factor analysis can be performed with confidence in the established validity and reliability.

Table 3: Exploratory factor analysis

\begin{tabular}{|c|c|c|c|}
\hline FACTOR & Cronbach's Alpha & AVE $^{*}$ & CR \\
\hline Contents & 0.832 & 0.696 & 0.901 \\
\hline ATTRIBUTES & Component Matrix & \multicolumn{2}{|c|}{ \% Variance Explained } \\
\hline Learning & 0.862 & \multirow{4}{*}{\multicolumn{2}{|c|}{69.598}} \\
\hline Design and structure & 0.856 & & \\
\hline Navigation & 0.788 & & \\
\hline Composition of contents & 0.829 & & \\
\hline FACTOR & Cronbach's Alpha & AVE & CR \\
\hline Usability & 0.914 & 0.553 & 0.828 \\
\hline ATTRIBUTES & Component Matrix & \multicolumn{2}{|c|}{ \% Variance Explained } \\
\hline Personalization & 0.822 & \multirow{4}{*}{\multicolumn{2}{|c|}{54.987}} \\
\hline Interactivity & 0.726 & & \\
\hline Privacy and security & 0.815 & & \\
\hline Memorability & 0.578 & & \\
\hline FACTOR & Cronbach's Alpha & AVE & CR \\
\hline Functionality & 0.808 & 0.932 & 0.965 \\
\hline ATTRIBUTES & Component Matrix & \multicolumn{2}{|c|}{ \% Variance Explained } \\
\hline Access & 0.977 & \multirow{2}{*}{\multicolumn{2}{|c|}{95.496}} \\
\hline Functional design & 0.954 & & \\
\hline FACTOR & Cronbach's Alpha & AVE & CR \\
\hline Branding & 0.913 & 0.662 & 0.852 \\
\hline ATTRIBUTES & Component Matrix & \multicolumn{2}{|c|}{ \% Variance Explained } \\
\hline Product type & 0.871 & \multirow{3}{*}{\multicolumn{2}{|c|}{66.262}} \\
\hline Pack components & 0.905 & & \\
\hline Product browser & 0.641 & & \\
\hline
\end{tabular}

The simplest approach to test the hypotheses would rely on linear regression models [137]. Linear estimations can provide useful initial insights into the relationship between the explanatory variables and the dependent variable, as well as an intuitive way to interpret coefficients, but their use also has been criticized when the relationships being evaluated are not linear. A General Additive Model (GAM) [60] offers a flexible alternative that relaxes the assumption of linearity between the dependent and independent variables by fitting natural splines for each covariate [115], while maintaining the coherent inference between the explanatory and dependent variables. The technique also has advantages over more restrictive linear models, because the explanatory variables are too complex to be represented by linear functions, that is to say, the structure of the data is complex and it is difficult to define a function which estimates the relationship correctly. Thus it is possible to check for the possible presence of non-linear relationships between covariates and outcomes, without making a priori assumptions about the degree of non-linearity [145]. Analytically, it can be expressed as follows:

$$
Y_{i}=\beta_{0}+\sum_{j=1}^{4} s_{j}\left(X_{j, i}\right)+\varepsilon_{i} i=1, \ldots n
$$

Trinidad Domínguez Vila Elisa Alén González Nelia Araújo Vila José Antonio Fraiz Brea 
where $Y$ is the dependent variable, the covariables $X_{j} \mathrm{j}=1, \ldots 4$ result from the previous factorial analysis, and the error term $\varepsilon$ is assumed to have zero mean and constant variance. The functions $\mathbf{s}$ are unknown soft functions that verify $E\left[s_{j}\left(X_{j}\right)\right]=0$ for $j=1, \ldots 4$.

The smoothness of each function $s$ is controlled by a smoothness parameter [6], expressed by the number of degrees of freedom or effective parameters for each function. With these methodological considerations, the GAM was estimated using $\mathrm{R}$ software. The confidence band is estimated for the additive model, and every component of the model is identified on the $x$-axis as a non-parametric: $S_{1}\left(X_{1}\right)$ for fact1_1, $S_{2}\left(X_{2}\right)$ for fact2_1, $S_{3}\left(X_{3}\right)$ for fact3_1, and $S_{4}\left(X_{4}\right)$ for fact4_1. The shapes of the smooth functions estimated for the four factors appear in Figure 1; despite their wiggly forms, the functions exhibit a global tendency in each case. Thus, for factors 1 (Contents) and 4 (Branding), linear smoothing can be used, but it cannot be for factors 2 (Usability) and 3 (Functionality).

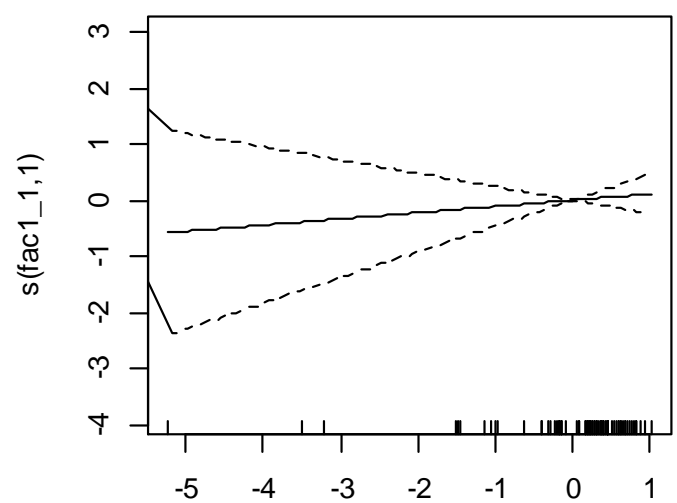

fac1_1

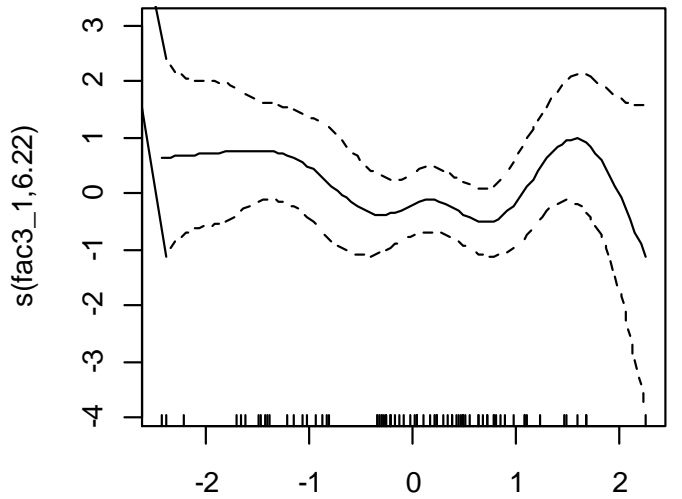

fac3_1

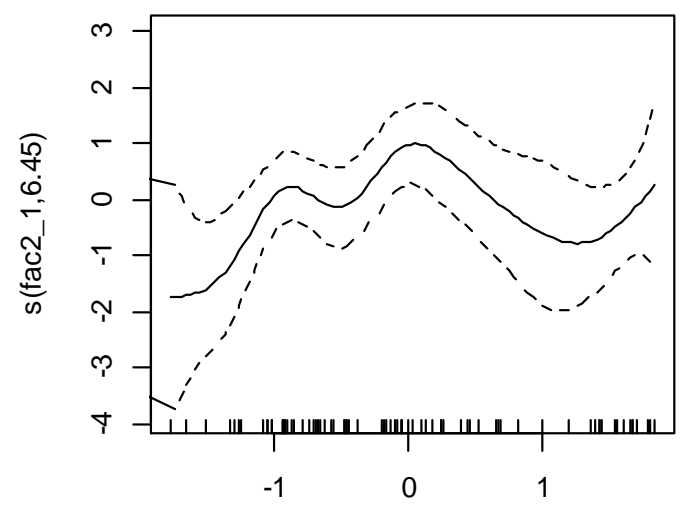

fac2_1

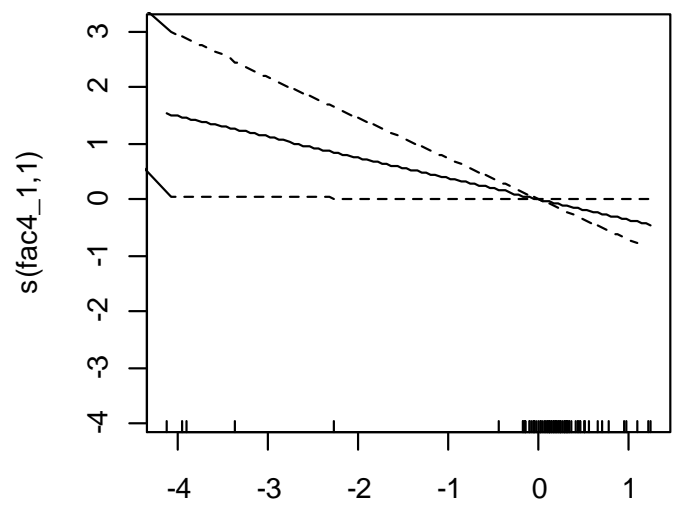

fac4_1

Figure 1: Graph of the non-parametric estimates of each component of the additive model

In relation to the different hypotheses, the $p$-value selected was $p \leq 0.1$. In theory, the value of $p$ is a continuous measure of the evidence, but in practice it is typically trichotomized approximately in highly significant, marginally significant and not statistically significant at conventional levels, with cut-offs at $p \leq 0.01, p \leq 0.05$ and $p \leq 0.10$ [13]. Therefore, if $p$ is between 0.1 and 0.9 , there is certainly no reason to suspect about the hypothesis tested [57], so we can accept as a successful hypothesis all those with a p value below 0.1 , since most of the statistics manuals present a gold rule of $0.1,0.05$ and 0.01 meanings levels [53]. The results in Table 4 show that the usability and branding factors had significant effects on the user experience, in support of $\mathrm{H} 2$ and $\mathrm{H} 4$. The acceptance of the $\mathrm{H} 2$ agrees with several existing works [23], [40], [41], [86], [135], [136]. Usability is a determining factor to achieve a better user's experience, which to acquire higher levels of satisfaction, trust, and loyalty toward a website [77]. Attributes as the personalization, interactivity and the privacy and security become determinative elements of the user experience. A customized website that enhances usability, reflecting the needs and preferences of the user, while respecting the privacy and security of the information, are hallmarks of future success [27], especially when accounting for the ongoing increases in uses of mobile devices for e-commerce [25]. The most important means to improve the user experience thus are customization and website interactivity, which helps customize the contents according to different consumption habits or groups. For this reason, the personalization is a key element, and a lot of users rank it as the second in importance in determining

Trinidad Domínguez Vila Elisa Alén González Nelia Araújo Vila José Antonio Fraiz Brea 
an e-tourism website's, at $57.5 \%$, such that customers care about being recognized by the website and being treated as an individual [98]

Moreover, a significant relationship arises between branding and user experience $(\mathrm{H} 4)$. Branding offers information about tourism products and services, influenced by new trends, so this factor has direct effects on users. The information about the product is fundamental. Products and support for product search are determinants of the navigation experience [80], and websites that provide clear and complete product and price information produce more satisfying experiences [22] and lead to better attitudes [78].

Table 4: Estimate of GAM mode

\begin{tabular}{|l|l|l|l|l|}
\hline & Edf & Coefficient & p-value & $\begin{array}{l}\text { Level p-value }> \\
0.1\end{array}$ \\
\hline Intercept & & 4.239 & 0.000 & \\
\hline $\mathrm{s}$ (Contents) & 1 & 0.402 & 0.5284 & Rejected H1 \\
\hline $\mathrm{s}$ (Usability) & 6.455 & 1.997 & 0.0810 & Supported H2 \\
\hline $\mathrm{s}$ (Functionality) & 6.221 & 1.451 & 0.2033 & Rejected H3 \\
\hline $\mathrm{s}$ (Branding) & 1 & 4.219 & 0.0442 & Supported H4 \\
\hline GCV score & & 2.593 & & \\
\hline $\begin{array}{l}\text { Adjusted R- } \\
\text { squared }\end{array}$ & 0.372 & & \\
\hline
\end{tabular}

The relationship between contents and user experience is not significant (cf. $\mathrm{H} 1$ ). Muhtaseb et al. [98] argue that users want the websites they visit to provide fresh, abundant, correct, pertinent, and timely information content, along with clear topics that are easy to understand. However, users might take this for granted when visiting a website, such that only the absence or low quality of contents affects their evaluation, generally negatively. Website designers thus must seek ways to improve consumer satisfaction through website content, in the form of its design and structure [99]. In research based on a classification of 385 metrics using a web quality model, Calero et al. [23] do not identify content as a key metric. Presentation, with $43.9 \%$, is the main factor, followed by content and navigation. Usability does stand out as a determinant for two of three higher-level metrics (usability, operation, presentation, with 149 metrics; usability, maintenance, presentation, with 93 metrics). These results are similar to the findings from this study, but the difference is that learning was not taken into account, despite it representing an attribute of the products on offer. This attribute cites key elements to facilitate the user experience, such as familiarity, consistency, generalizability, predictability, and simplicity [14], [15], [98], [104].

With regard to functionality, the websites do not have statistically significant influences on the user experience (H3). This technical element encompasses processes and applications that are not directly visible to the user [39], and websites made less effort with it than for the other factors. Such efforts are practically limited to meeting standards of correct usage. For the dimension of quality characteristics [23], users identify functionality as one of the least relevant determinants of website quality; they mainly emphasize usability, at the expense of other elements. The vast majority of websites also use badges issued by the World Wide Web Consortium (W3C), which imposes parameters and check points that must be met to achieve accessibility, as reflected in Web Content Accessibility Guidelines (WCAG) 2.0. Although perhaps at one time, "the most important aspect of a website was usability, but now accessibility plays a very important role" [23]. Still, it remains essential to ensure the accessibility of official tourism websites, to eliminate any barriers [119] and make comprehensive information about the accessibility of different tourism elements readily available [119].

\section{Conclusions}

In this paper, it is concluded that on one hand, the tourist search and metasearch engines and based on the current researches, the consumers' behavior is very similar and does not distinguish them. One of these papers shows that the level structure of both types of browsers are similar, even if the interface of metasearch engines can be better than search engines in terms of privacy, security, and personalization/customization [47]. The offer content level as a function of the type of offer and the component (metasearch engines focus on flights and accommodation; search engines have a general offer) shows that the number of search engines is not a determining factor [47]. However, it remains essential to continue improving the user experience, in terms of performing e-commerce operations, such as by reducing search process time and website personalization to meet the needs of users. For this, the number of search engines, and therefore, the main difference between search and metasearch engines, is increasingly determining, as well as establishing the most relevant website design variables that influence the user experience.

On the other hand, the explanatory variables about the user experience of an e-tourism website design are too complex to be explained by linear functions, considering the use of the GAM more appropriate. With this methodology, it was possible to observe the influence of usability and branding factors on user experiences, and the lack of relevance of contents and functionality. This is the main contribution of this paper, which shows a list of factors and attributes that influence directly in the user experience of e-tourism websites. Based on the results in a more concrete way, the user 
experience of an e-tourism website relates positively to its usability, and consequently, e-commerce search and metasearch engines in the tourism industry should devote substantial efforts to implementing interactivity, memorability, personalization, privacy, and security. Users want the websites they consult to securely adapt to their wants and needs (while ensuring privacy), and they expect that the specific profile/interface of the product on offer will be maintained, without having to select it on every visit. To improve usability, some options are to communicate in real time with users, provide interactive decision aids, rely on social media (e.g., social networking, media file sharing on sites like YouTube), offer virtual dialogue, provide recommendations, establish a history setting, and allow users to select advertising preferences. Brand equity has been recognized as a competitive advantage that requires constant maintenance and progress to ensure rewarding, long-term outcomes in marketing environments [126]. Users no longer simply acquire a tourism product or service; they seek experiences. Rich and interactive experiences can improve customers' evaluations of a brand, because they are more affective and cognitively intense [18], and increase the quality and number of comments in social networks. Brand value in virtual contexts yields various positive consequences, including persuasion, attitude beliefs, product beliefs, product awareness, attitude toward the brand, attitude change, purchase consideration, customer confidence, purchase intentions, user satisfaction, and behavioral changes [106].

In general, although there are more and more researches about tourism websites, they are still few little research about the variables related to website design [3], [13], [54], [93], [94], [102], [118], [122], and even less about their impacts on the user experience in the tourism sector [3], [13], [99]. Nowadays, the main success element on the e-commerce tourism is to develop efficient and efficacy processes, which involves planning, decision making, and anticipation of the trip with other people and guarantee accuracy information [61]. Thus, it is fundamental to establish the main attributes of tourism search and metasearch website designs and their influence on the user experience, which can produce new strategies for the industry. Therefore, this involves determining whether to use search or metasearch engines, as well as establishing the main attributes of the website design.

Highlight as important implication by the industry that branding can be a key means to personalize content, because it reflects key product elements, resulting in hundreds of possible combinations and variables, depending on the website visited. It is difficult to manage though, because tourism is critically based on experience. It may be possible to pursue a better use of synergies among tourism products; some websites already share search engines. Contents and functionality do not influence the user experience; users generally just assume their existence. Only their non-existence might have a negative influence on the user experience.

Finally, is very important mentioned that this study has several limitations. First, the low proportion of user experience accounted for probably results from the influence of other variables that could provide a better explanation of the model but that were not included. Some of the variables used to construct the model came from other research domains, due to the lack of specific studies of user experiences with search and metasearch engines in the tourism sector, which complicate the establishment of a robust theoretical framework. Second, the sampling process was limited by the search terms, which could be expanded to include a greater number and wider range of terms. Further research also might test the proposed model in other tourist sectors, as well as continue identifying new elements, such as collaborative customer relationship management (CRM) and new communication models linking supply and demand, which could help improve the representativeness of the model for explaining user experiences.

\section{References}

[1] M. R. Ab Hamid, Z. Mustafa, N. R. Mohd Suradi, M. Abdullah, W. R. Ismail, Z. Mohamad Ali, F. Idris, S. R. Yaziz, and M. Z. Ismail, Value-based total performance excellence model: An overview, Journal Technology, vol. 52, pp. 95-104, 2010.

[2] F. Abbatista, M.D.O.Licchelli, P. Lops, G. Semerao, and F. Zambetta, Improving the usability of an e-commerce web site through personalization, in Proceedings of the Workshop on Recommendation and Personalization in Electronic Commerce, 2nd International Conference on Adaptative Hypermedia and Adaptative Web Based Systems, University of Bari, 1999, pp. 1-10.

[3] E. G. Abeles, M. D. White and K. Hahn, A user-based design process for web sites, OCLC Systems and Services, vol. 15, no. 1, pp. 35-44, 1999.

[4] M. Aghekyan-Simonian, S. Forsythe, W.S. Kwon and V. Chattaraman, The role of product brand image and online store image on perceived risks and online purchase intentions for apparel, Journal of Retailing and Consumer Services, vol. 19, pp. 325-331, 2012.

[5] Y. Akgül and K. Vatansever, Web accessibility evaluation of government websites for people with disabilities in Turkey, Journal of Advance Management, vol. 4, no. 3, pp. 201-210, 2016.

[6] M. Aldrin and I. Hobæk Haff, Generalised additive modelling of air pollution, traffic volume and meteorology, Atmospheric Environment, no. 39, pp. 2145-2155, 2005

[7] M. E. Andrés, M. A. Gómez and J. A. Mondéjar, A model to evaluate the effects of price fairness perception in online hotel booking, Electronic Commerce Research, vol. 14, pp. 171-187, 2014.

[8] A.S.M. Arif, J.T. Du and I. Lee, Collaborative information retrieval in tourism: a study of user search behavior, user interface and information retrieval performance, in Proceedings of the 4th Information Interaction in Context Symposium, New York: ACM Press, 2012, p. 326.

[9] I. Arsal, K.M. Woosnam, E.D. Baldwin, and S.J. Backman, Residents as travel destination information providers: An online community perspective, Journal of Travel Research, vol. 49, no. 4, pp. 400-413, 2010. 
[10] T. Au Yeung and R. Law, Usability evaluation of Hong Kong hotel websites, in Information and Communication Technologies in Tourism (A. J. Frew, M. Hitz and P. O'Connor, Eds). Austria: Springer, 2003, pp. 261-269.

[11] R. P. Bagozzi and Y. Yi, On the evaluation of structural equation models, Journal of the Academy of Marketing Sciences, vol. 16, no. 1, pp. 74-94, 1988.

[12] R. P. Bagozzi, Y. Yi and L. W. Phillips, Assessing construct validity in organizational research, Administrative Science Quarterly, vol. 36, no. 3, pp. 421-458, 1991.

[13] S. Baloglu and A. Pekcan, The website design and the internet site marketing practices of upscale and luxury hotels in Turkey, Tourism Management, vol. 27, no. 1, pp. 171-176, 2006.

[14] H. Banati, P. Bedi and P. S. Grover, Evaluating web usability from the user's perspective, Journal of Computer Science, vol. 2, no. 4, pp. 314-317, 2006

[15] S. J. Barnes and R. Vidgen, Measuring website quality improvements: A case study of the forum on strategic management knowledge exchange, Industrial Management and Data System, vol. 103, no. 5, pp. 297-309, 2003.

[16] U. Bastida and T.C. Huan, Performance evaluation of tourism websites' information quality of four global destination brands: Beijing, Hong Kong, Shanghai and Taipei, Journal of Business Research, vol. 67, no. 2, pp. 167-170, 2014

[17] M. Bernardo, F. Marimon and M. del Mar Alonso-Almeida, Functional quality and hedonic quality: A study of the dimensions of e-service quality in online travel agencies, Information \& Management, vol. 49, no. 7-8, pp. 342$347,2012$.

[18] A. Bilgihan, Gen Y customer loyalty in online shopping: an integrated model of trust, user experience and branding, Computers in Human Behavior, vol. 61, pp. 103-113, 2016.

[19] K. A. Bollen, Structural Equations with Latent Variables. New York: John Wiley \& Sons, Inc., 1989.

[20] M. A. Bonn, H. L.Furr and A. M. Susskind, Using the internet as a pleasure travel planning tool: An examination of the sociodemographic and behavioral characteristics among internet users and nonusers, Journal of Hospitality \& Tourism Research, vol. 22, no. 3, pp. 303-317, 1998.

[21] D. Buhalis and R. Law, Progress in information technology and tourism management: 20 years on and 10 years after the Internet - The state of eTourism research, Tourism Management, vol. 29, no. 4, pp. 609-623, 2008.

[22] R. Burke, Technology and the customer interface: What consumers want in the physical and virtual store, Academy of Marketing Science, vol. 30, no. 4, pp. 411-432, 2002.

[23] C. Calero, J. Ruiz and M. Piattini, Classifying web metrics using the web quality model, Online Information Review, vol. 29, no. 3, pp. 227-248, 2005.

[24] X. Cao and P. L. Mokhtarian, The intended and actual adoption of online purchasing a brief review of recent literature, Institute of Transportation Studies (ITS), Department of Civil and Environmental Engineering, Working paper, University of California, 2005.

[25] J. Carlshamre, A usability perspective on requirements engineering - from methodology to product development, Institute of Technology, Linköpings Universitet, 2001.

[26] J. Carlson and A. O'Cass, Developing a framework for understanding e-service quality, its antecedents, consequences, and mediators, Managing Service Quality, vol. 21, no. 3, pp. 264-286, 2011

[27] L. Caruccio, V. Deufemia, C. D'Souza, A. Ginige, and G. Polese, A tool supporting end-user development of Access control in web applications, International Journal of Software Engineering and Knowledge Engineering, vol. 25, no. 2, pp. 307-331, 2015.

[28] J. Chang, Usability evaluation of B2C e-commerce website in China, in Proceedings The Sixth Wuhan International Conference on E-Business, China, Zhengzhou, Institute of Aeronautical Industry Management, 2007, pp. 53-59.

[29] B.Y. Chang, M.J. Magobe and Y.B. Kim, E-commerce applications in the tourism industry: A Tanzania case study, South African Journal of Business Management, vol. 46, no. 4, pp. 53-63, 2015.

[30] W. W. Chin, A. Gopal and W.D. Salisbury, Advancing the theory of adaptive structuration: The development of a scale to measure faithfulness of appropriation, Information System Research, vol. 8, no. 4, pp. 342-367, 1997.

[31] W.C. Chiou, C.C. Lin and C. Perng, A strategic website evaluation of online travel agencies, Tourism Management, vol. 32, no. 6, pp. 1463-1473, 2011

[32] S. Choi, X.Y. Lehto and A.M. Morrison, Destination image representation on the web: Content analysis of Macau travel related websites, Tourism Management, vol. 28, no. 1, pp. 118-129, 2007.

[33] M. M. Choudhury and P. Harrigan, CRM to social CRM: The integration of new technologies into customer relationship management, Journal of Strategic Marketing, vol. 22, no. 2, pp. 149-176, 2014.

[34] S. Chu, Viral advertising in social media: Participation in Facebook groups and responses among college-aged users, Journal of Interactive Advertising, vol. 12, no. 1, pp. 30-43, 2011

[35] C. Cox, S. Burgess, C. Sellito, and J. Buultjens, The role of user generated content in tourists' travel planning behavior, Journal of Hospitality Marketing and Management, vol. 18, no. 8, pp. 743-764, 2009.

[36] Creative Katalyst. Branded websites: The best thing you can do for your business, United States, Katalyst, 2012.

[37] I. H. Crnojevac, J. Gugié and S. Karlovčan, eTourism: A comparison of online and offline bookings and the importance of hotel attributes, Journal of Information and Organization Sciences, vol. 34, no. 1, pp. 41-54, 2010.

[38] G. I. Crouch, Modelling destination competitiveness. A survey and analysis of the impact of competitiveness attributes. Australia: CRC for Sustainable TourismPty Ltd., 2007.

[39] D. Cunliffe, Developing usable websites: A review and model internet research, Electronic Networking Application and Policy, vol. 10, no. 4, pp. 295-307, 2000.

[40] V. Davidavičienè and J. Tolvaišas, Measuring quality of e-commerce web sites: Case of Lithuania, Economics and Management, vol. 16, pp. 723-729, 2011. 
[41] F. D. Davis, R. P. Bagozzi and P. R. Warshaw, User acceptance of computer technology: A comparison of two theoretical models, Management Science, vol. 35, no. 8, pp. 982-1003, 1989.

[42] J. Deighton, The future of interactive marketing, Harvard Business Review, vol. 74, no. 6, pp. 151-160, 1996.

[43] J. Delgado and R. Davidson, Knowledge bases and user profiling in travel and hospitality recommender systems, in Proceedings of the ENTER 2002 Conference, Innsbruck, Austria. Springer Verlag, 2002, pp. 1-16.

[44] L. Derong, Z. Zoangqing and G. Xiaolin, A study of the website performance of travel agencies based on the EMICA model, Journal of Service Science \& Management, vol. 2, no. 3, pp. 181-185, 2009.

[45] R. F. DeVilles, Scale Development: Theory and Applications. Applied Social Research Series 26. Newbury Park: Sage, 2012.

[46] A. Dix, F. Finlay, G. Abowd and R. Beale, Human-Computer Interaction, Second Edition, Prentice Hall, 2003.

[47] T. Domínguez, N. Araújo, E. Alén and J.A. Fraiz, The role of the internat as a tool to search for tourism information, Journal of Global Information Management, vol. 26, no. 1, pp. 58-84, 2018.

[48] T. Domínguez, S. Darcy and E. Alén, Competing for the disability tourism market - A comparative exploration of the factors of accessible tourism competitiveness in Spain and Australia, Tourism Management, vol. 47, pp. 261$272,2015$.

[49] J. Eighmey, Profiling user responses to commercial website, Journal of Advertising Research, vol. 37, no. 3, pp. 59-66, 1997.

[50] Eurostat. (2018) Digital economy \& society in the EU. A browse through our online world in figures. Eurostat. [Online]. Available: https://ec.europa.eu/eurostat/web/products-digital-publications/-/KS-04-18-130

[51] J. Fernández-Cavia, C. Rovira, P. DíazLuque, and V. Cavaller, Web quality index (WQI) for official tourist destination websites. Proposal for an assessment system, Tourism Management Perspectives, vo. 9, p. 513, 2014.

[52] D. R. Fesenmaier, Z. Xiang, B. Pan, and R. Law, A framework of search engine use for travel planning, Journal of Travel Research, vol. 50, no. 6, pp. 587-601, 2011

[53] D. B. Figueiredo, R. Paranhos, M. B. J. A. da Silva, M. L. Wanderley, and J. Guiro, When is statistical significance not significant? Brazilian Political Science Review, vol. 7, no. 1, pp. 31-55, 2003.

[54] C. Flavian, R. Gurrea and C. Orús, Web design: A key factor for website success, Journal of Systems and Information Technology, vol. 11, no. 2, pp. 168-184, 2009.

[55] A. Floh and M. Madlberger, The role of atmospheric cues in online impulse-buying behavior, Electronic Commerce Research and Applications, vol. 12, pp. 425-439, 2013

[56] C. Fornell and D.F. Larker, Structural equation models with unobservable variable and measurement error: Algebra and statistics, Journal of Marketing Research, vol. 18, no. 3, pp. 382-388, 1981.

[57] A. Gelman. (2012, February) The inevitable problems with statistical significance and 95\% intervals, Statistical Modeling, Causal Inference, and Social Science. [Online]. Available: https://statmodeling.stat.columbia.edu/?s =The+inevitable+problems+with+statistical+significance+and+95\%25+intervals

[58] A. Gunasekaran and E.W.G. Ngai, Build-to-order supply chain management: A literature review and framework for development, Journal of Operations Management, vol. 23, pp. 423-451, 2005

[59] W. Hanson, Principles of Internet Marketing. Cincinnati: South- Western College Publishing, 2000.

[60] T. J. Hastie and R.J. Tibshirani, Monographs on Statistics and Applied Probability. Chapman \& Hall, 1990.

[61] A. Hausman and J. Siekpe, The effect of web interface features on consumer online purchase intentions, Journal of Business Research, vol. 62, no. 1, pp. 5-13, 2009.

[62] B. Hernandez, J. Jimenez and M.J. Martín, Adoption vs. acceptance of e-commerce: Two different decisions, European Journal of Marketing, vol. 43, no. 9/10, pp. 1232-1245, 2009.

[63] C. Ho, M.H. Lin and H. M. Chen, Web users behavioural patterns of tourism information search: From online to offline, Tourism Management, vol. 33, no. 6, pp. 1468-1482, 2012.

[64] C. Ho and Y. L. Yuang, The search strategies of smartphone user for tourism information: A reflection of big data, ACM, no. 61, pp. 7-9, 2015.

[65] L. Hu, K. Lin, M. Mehedi, A. Alamri, and A. Alelaiwi, CFSF: On cloud-based recommendation for large-scale ecommerce, vol. 20, no. 3, pp. 380-390, 2015.

[66] D. lacobucci, P. Arabie and A. Bodapati, Recommendation agents on the internet, Journal of Interactive Marketing vol. 14, no. 3, pp. 2-11, 2000.

[67] A. Inversini, L. Cantoni and M. De Pietro, Destination online communication: why less is sometimes more. A study of online communications of English destinations, Journal of Travel \& Tourism Marketing vol. 31, no. 5, pp. 563$575,2014$.

[68] C. Ip, H. Lee and R. Law, Profiling the users of travel websites for planning and online xperience sharing, Journal of Hospitality \& Tourism Research, vol. 36, no. 3, pp. 418-426, 2012.

[69] Ipsos Media CT and Google Travel Study. (2016, January) The 2015 traveler's road to decision: affluent insights. Think insights Google January 22. [Online]. Available: https://think.storage.googleapis.com/docs/travelers-roadto-decision-affluent-insights research-studies.pdf

[70] B. Jamshidi, Web usability in B2B websites: Users' perspective, M.S. thesis, Lulea University of Technology, Luleå, Sweden, 2008.

[71] S. Jang, The past, present, and future research of online information search, Journal of Travel \& Tourism Marketing, vol. 17, no. 2/3, pp. 41-47, 2004.

[72] S. Jayachandran, S. Sharma, P. Kaufman, and P. Raman, The role of relational nformation processes and technology use in customer relationship management, Journal of Marketing, vol. 69, no. 4, pp. 177-192, 2005.

[73] S.H. Jun, C.A. Vogt and K.J. Mackey, Relationship between travel information search and travel product purchase in pre-trip contexts, Journal of Travel Research, vol. 45, no. 3, pp. 266-274, 2007. 
[74] A. Kamis and J. Frank, Advice shearing between paired users in online travel planning, Journal of Theoretical and Applied Electronic Commerce Research, vol. 9, no. 1, pp. 1-15, 2014.

[75] K. Kaplanidou, C. Vogt and D. Morris, Importance-performance analysis of destination marketing organization websites, in Proceedings the 36th Annual Conference of Travel Tourism Research Association, Boise, ID: Travel and Tourism Research Association, 2005, pp. 9-16.

[76] M. L. Kasavana, eMarketing: Restaurant website that click, Journal of Hospitality \& Leisure Marketing, vol. 9, no. 3/4, pp. 161-178, 2002.

[77] E.B. Kim and S.B. Eom, Designing effective cyber store user interface, Industrial Management and Data Systems, vol. 102, no. 5, pp. 241-251, 2002.

[78] M. Koufaris, Applying the technology acceptance model and flow theory to online consumer behavior, Information Systems Research, vol. 13, no. 2, pp. 205-223, 2002.

[79] M. Kuniavsky, Observing the User Experience: A Practitioner's Guide to User Research. San Francisco: Morgan Kaufmann, 2003

[80] I. Küster, N. Vila and P. Canales, How does the online service level influence consumers' purchase intentions before a transaction? A formative approach, European Journal of Management Business Economics, vol. 25, no. 3, pp. 111-120, 2016.

[81] T. Kuo, I.Y. Lu, C.H. Huang, and G.C. Wu, Measuring users' perceived portal service quality: An empirical study, Total Quality Management, vo. 16, no. 3, pp. 309-320, 2005.

[82] R. Law, S. Qi and D. Buhalis, A review of website evaluation in tourism research, Tourism Management, vol. 31, pp. 221-234, 2010

[83] R. Law and J. Wong, Successful factors for a travel website: Perceptions of online purchasers in Hong Kong, Journal of Hospitality \& Tourism Research, vol. 27, no. 1, pp. 118-124, 2003.

[84] A. Lawson-Body and M. Limayem, The impact of customer relationship management on customer loyalty: The moderating role of web site characteristics, Journal of Computer-Mediated Communication, vol. 9, no. 4, 2004.

[85] H. Y. Lee, H. Ahn and I. Han, Analysis of trust in the e-commerce adoption, in Proceedings of the 39th Hawaii International Conference on System Sciences, Big Island, HI, 2006, pp. 113-122.

[86] L. Li and D. Buhalis, eCommerce in China: The case of travel international, Journal of Information Management, vol. 26, no. 2, pp. 153-166, 2006.

[87] K. C. Ling, L.T. Chai and T.H. Piew, The effects of shopping orientations, online trust and prior online purchase experience toward customers' online purchase intention, International Business Research, vol. 3, no. 3, pp. 63$76,2010$.

[88] E. T. Loiacono, R.T. Watson and D. L. Goodhue, WebQual: An instrument for consumer evaluation of web sites, International Journal of Electronic Commerce, vol. 11, no. 3, pp. 51-87, 2007.

[89] T. Louis. (June, 2003) Usability 101: Learnability. Tnl.net. [Online]. Available: http://www.tnl.net/blog/2003/06/17/ usability-101-learnability/

[90] M. R. Luo, R. Feng and L. A. Cai, Information search behavior and tourist characteristics: The internet vis-a` -vis other information sources, Journal of Travel \& Tourism Marketing, vol. 17, no. 2/3, pp. 15-25, 2004

[91] E. Marlow. (2010, September). Website interactivity. Nonprofit Resource Center. [Online]. Available: http://www.nprcenter.org.

[92] N. Matsatsinis, E. Grigoroudis and P. Delias, User satisfaction and e-learning systems: Towards a multi-criteria evaluation methodology, Operational Research, vol. 3, no. 3, pp. 249-259, 2003.

[93] Ch. L. Mauro, Professional usability testing and its return on investment as it applies to user interface design for web-based products and services, Mauro New Media, pp. 1-57, 2002.

[94] L. Mich, M. Franch and L. Gaio, Evaluating and designing Web site quality, IEEE MultiMedia, vol. 10, no. 1, pp. 34-43, 2003.

[95] N. Mitsche, Understanding the information search process within a tourism domain specific search engine, in Information and Communication Technologies in Tourism (A. J. Frew, Ed.). Vienne: Springer, 2005, pp. 183-193.

[96] M. M. Montoya-Weiss, G.B. Voss and D. Grewal, Determinants of online channel use and overall satisfaction with a relational, multichannel service provider, Journal of the Academy of Marketing Science, vol. 31, no. 4, pp. 448-58, 2003.

[97] A. M. Morrison, S. Taylor and A. Douglas, Website evaluation in tourism and hospitality, Journal of Travel and Tourism Marketing, vol. 17, no. (2/3), pp. 232-251, 2004.

[98] R. Muhtaseb, K. Lakiotaki and N. Matsatsinis, Applying a multicriteria satisfaction analysis approach based on user preferences to rank usability attributes in e-tourism websites, Journal of Theoretical and Applied Electronic Commerce Research, vol. 7, no. 3, pp. 28-48, 2012.

[99] J. Murphy, E. J. Forrest, C.E. Wotring, and R.A. Brymer, Hotel management and marketing on the internet, Cornell Hotel \& Restaurant Administration Quarterly, vol. 37, no. 3, pp. 70-82, 1996.

[100]J. Nielsen, Usability Engineering, San Francisco: Morgan Kaufmann, 1993

[101]M. Niemann, M. Mochol and R. Tolksdorf, Enchancing hotel search with semantic web technologies, Journal of Theoretical and Applied Electronic Commerce Research, vol. 3, no. 2, pp. 82-96, 2008.

[102] J. Pallud and D. Straub, Effective website design for experience-influenced environments: The case of high culture museums, Information \& Management, vol. 51, no. 3, pp. 359-373, 2014.

[103] Pan and D.R. Fesenmaier, Online information search: Vacation planning process, Annals of Tourism Research, vol. 33, no. 3, pp. 809-832, 2006.

[104]A. Parasuraman, V. A. Zeithaml and A. Malhotra, E-S-QUAL: A multiple-item scale for assessing electronic servisse quality, Journal of Service Research, vol. 7, no. 3, pp. 13-33, 2007. 
[105] A. Park and U. Gretzel, Success factors for destination marketing websites: a qualitative meta-analysis, Journal of Travel Research, vol. 46, pp. 46-63, 2007.

[106] S.R. Park, F. Nah, D. DeWester, B. Eschenbrenner, and S. Jeon, Virtual world affordances: Enhancing brand value, Journal of Virtual Worlds Research, vol. 1, no. 2, pp. 1-18, 2008.

[107] Phocuswright. (2017, January) 2017 Online travel primer. Americas/United States Equity Research Consumer Internet. [Online] Available: https://research-doc.credit-suisse.com/docView?language=ENG\&format=PDF\&sour ceid=em\&document id=1069481691\&serialid=ZC0f4rMG6NDYAHrRvx8HChVrvrSWJ37rGgWzjf\%2b9fVM\%3d

[108] A. Pollock, Information technology and the emergence if a new tourism, Journal of Hospitality Management, vol. 2, pp. 49-56, 1995

[109] J.D. Power, Online Travel Agency Satisfaction Report. US: McGraw Hill Financial, 2014.

[110]S. Qi, R. Law and D. Buhalis, Usability of Chinese destination management organization websites, Journal of Travel \& Tourism Marketing, vol. 25, no. 2, pp. 1872-198, 2008.

[111]Z. Qin and L. Zhang, Customizable E-Commerce: Introduction, Application and Proposition. China: Xi'an Jiaotong University, 2001.

[112] M. Quaddus and D. Achjari, A model for electronic commerce success, Telecommunications Policy, vol. 29, no. 2-3, pp. 127-152, 2005

[113] R. Rajshekhar, G. Javalgi, B.D. Cutler, and R.B. Young, The influence of culture on services marketing research, Services Marketing Quarterly, vol. 27, no. 2, pp. 103-121, 2005

[114] H. Read. (2019, January) SEM vs SEO, what's the difference? Marketing Manager, PPC Associated. [Online]. Available: https://www.reliablecounter.com/blog/sem-vs-seo-whats-difference/

[115]S. Reiss, Legend as Unique Selling Proposition for the Marketing of Destinations: The Case of Glastonbury and the Legend of King Arthur. United Kingdom: University of Bournemouth, 2006.

[116]V. A. Reston. (2015, August) Releases July 2015 U.S. desktop search engine rankings. comScore. [Online]. Available: $\quad$ http://www.comscore.com/Insights/Market-Rankings/comScore-Releases-July-2015-U.S.-DesktopSearch-Engine-Rankings

[117] S. A. Roney and M. Özturan, A content analysis of the Web sites of Turkish travel agencies, Anatolia: An International Journal of Tourism and Hospitality Research, vol. 17, no. 1, pp. 43-54, 2006.

[118]E. Rosen and E. Purinton, Website design: viewing the web as a cognitive landscape, Journal of Business Research, vol. 57, pp. 787-94, 2004.

[119]H. Rumetshofer and W. Wöss, Tourism information systems promoting barrier-free tourism for people with disabilities, in Computers Helping People with Special Needs. (K. Miesenberger, J. Klaus, W. Zagler, and D. Burger, Eds.). Berlin: Springer Verlag, 2004, pp. 280-286.

[120]J. Santos, E-service quality: A model of virtual service quality dimensions, Managing Service Quality: An International Journal, vol. 13, no. 3, pp. 233-246, 2003.

[121]A. Scharl, K. Wöber and C. Bauer, An integrated approach to measure web site effectiveness in the European hotel industry, Information Technology and Tourism, vol. 6, no. 4, pp. 257-271, 2004

[122] R. Schegg, T. Steiner, S. Frey, and J. Murphy, Benchmarks of websites design and marketing by Swiss Hotels, Information Technology and Tourism, vol. 5, pp. 73-89, 2002.

[123]Y. Shi, The accessibility of Queensland visitor information centres' websites, Tourism Management, vol. 27, no. 5, pp. 829-841, 2006

[124] Spanish Association of Branding Companies (Asociación Española de Empresas de Branding. AEBRAND). (2002) ¿Qué es branding?. Branderstand. [Online]. Available: http://www.branderstand.com/que-es-para-ti-elbranding/

[125]A. Spink and B.J. Jansen, Web Search: Public Searching of the Web. Dordrecht: Springer, 2004

[126]S. Sriram, S. Balachander and M.U. Kalwani, Monitoring the dynamics of brand equity using store-level data, Journal of Marketing, vol. 71, no. 2, pp. 61-78, 2007.

[127] R. Steinmetz, Food, tourism and destination: The case of Rotorua. New Zealand, Tourism Management, vol. 30, pp. 974-981, 2010 .

[128]S. Stepchenkova, L. Tang, S.C. Jang, A.P. Kirilenko, and A.M. Morrison, Benchmarking CVB website performance: Spatial and structural patterns, Tourism Management, vol. 31, no. 5, pp. 611-620, 2010.

[129]T. Stewart. (2008) Usability or user experience - what's the difference? System Concepts. [Online]. Available: http://www.system-concepts.com/articles/usability\%20\&\%20hci/usability\% 20or\%20user\%20experience\% $20 \%$ 11\%20what's\%20the\%20difference?

[130] V. Swaminathan, E. Lepkowska-White and B.P. Rao, Browsers or buyers in cyberspace? An investigation of factors influencing electronic exchange, Journal of Computer Mediated Communication, vol. 5, no. 2, 1999.

[131] T. Szopiński and M. W. Staniewski, Socio-economic factors determining the way e-tourism is used in European Union member states, Internet Research, vol. 26, no. 1, pp. 2-21, 2016.

[132] Titan, L. S. Sanjaya, Ferdianto, Influential factors on travel decision in e-tourism, in Proceedings of 2016 International Conference on Information Management and Technology, ICIMTech 2016, 2017, pp. 272-276.

[133]E. Turban, N. Bolloju and T.P. Liang Enterprise social networking: Opportunities, adoption, and risk mitigation, Journal of Organizational Computing and Electronic Commerce, vol. 21, no. 3, pp. 202-220, 2011.

[134] Vallet, eBranding, La creación de marca digital en la era de la conectividad, PhD. Dissertation, Universidad Autónoma de Barcelona, U.A.B., Barcelona, 2005.

[135]L. R. Vijayasarathy, Predicting consumer intentions to use on-line shopping: The case for an augmented technology acceptance model, Information \& Management, vol. 41, pp. 747-762, 2004. 
[136]K. W. Wöber, Domain-specific search engines, in Destination recommendation systems: behavioral foundations and applications (D. R. Fesenmaier, K. W. Wöber and H. Werthner, Eds.). Wallingford, UK: CAB International, 2003, pp. 205-226.

[137] M. Wooldridge, Reasoning about Rational Agents. Cambridge, Mass: MIT Press, 2000.

[138] World Tourism Organization. (2018, September) UNWTO, Tourism highlights 2018 Edition, 2018, World Tourism Organization UNWTO. [Online]. Available: https://www.e-unwto.org/doi/pdf/10.18111/9789284419876

[139] P.C. Wright and M. Blythe, User experience research as an inter-discipline: Towards a UX Manifesto, in Towards a UX Manifesto - Proceedings of a cost affiliated workshop on BHCl (E. Law, A. Vermeeren, M. Hassenzahl, and M. Blythe, Eds.). Lancaster, UK: Cambridge University Press, 2007, pp. 65-70.

[140]Z. Xiang and U. Gretzel, Role of social media in online travel information search, Tourism Management, vol. 31, pp. 179-188, 2010.

[141]Z. Xiang, K. Wöber and D. R. Fesenmaier, Representation of the online tourism domain in search engines, Journal of Travel Research, vol. 47, no. 2, pp. 137-150, 2008.

[142] L. Xiang, X. Zheng, M.K. Lee and D. Zhao, Exploring consumers' impulse buying behaviour on social commerce platform: The role of parasocial interaction, International Journal of Information Management, vol. 36, no. 3, pp. 333-347, 2016.

[143] Y. Yua, X. Wanga, R.Y. Zhongb, and G. Q. Huanga, E-commerce logistics in supply chain management: Practice perspective, Procedia CIRP, vol. 52, pp. 179-185, 2016.

[144] P. Zaharias and A. Poylymenakou, Developing a usability evaluation method for e-learning applications: Beyond functional usability, International Journal of Human-Computer Interaction, vol. 25, no. 1, pp. 75-98, 2009.

[145] I. Zanin and G. Marra, A comparative study of the use of generalized additive models and generalized linear models in tourism research, International Journal of Tourism Research, vol. 14, pp. 451-468, 2012.

[146]X. Zhao, Y. Liu, H. Bi, and R. Law, Influence of coupons on online travel reservation service recovery, Journal of Hospitality and Tourism Management, vol. 21, pp. 18-26, 2014.

[147] A. H. Zins, U. Bauernfeind, F. Missier, A. Venturini, and H. Rumetshofer, An experimental usability test for different destination recommender systems, in Information and Communication Technologies in Tourism (A. Frew, Ed.). Wien New York: Cairo. Springer, 2004, pp. 228-238. 


\section{Appendix A: Data Collected: Number of Search Results}

\begin{tabular}{|c|c|c|c|c|c|}
\hline & Accommodation & Trip & Travel & Transport & Booking \\
\hline USA & $195,000,000$ & $327,000,000$ & $574,000,000$ & $695,000,000$ & $224,000,000$ \\
\hline Spain & $118,000,000$ & $257,000,000$ & $309,000,000$ & $234,000,000$ & $161,000,000$ \\
\hline China & $122,000,000$ & $233,000,000$ & $470,000,000$ & $397,000,000$ & $110,000,000$ \\
\hline France & $161,000,000$ & $378,000,000$ & $491,000,000$ & $543,000,000$ & $173,000,000$ \\
\hline Italy & $133,000,000$ & $235,000,000$ & $362,000,000$ & $282,000,000$ & $189,000,000$ \\
\hline UK & $332,000,000$ & $400,000,000$ & $843,000,000$ & $694,000,000$ & $297,000,000$ \\
\hline Germany & $147,000,000$ & $216,000,000$ & $416,000,000$ & $551,000,000$ & $167,000,000$ \\
\hline Thailand & $72,300,000$ & $110,000,000$ & $162,000,000$ & $134,000,000$ & $97,800,000$ \\
\hline Total & $1,119,300,000$ & $2,156,000,000$ & $3,627,000,000$ & $3,530,000,000$ & $1,418,000,000$ \\
\hline Filter 1 & \multicolumn{5}{|l|}{ Tourism } \\
\hline USA & $30,100,000$ & $82,800,000$ & $98,700,000$ & $44,700,000$ & $43,000,000$ \\
\hline Spain & $31,000,000$ & $87,500,000$ & $110,000,000$ & $30,300,000$ & $42,300,000$ \\
\hline China & $31,300,000$ & $63,400,000$ & $127,000,000$ & $53,000,000$ & $30,500,000$ \\
\hline France & $36,200,000$ & $107,000,000$ & $153,000,000$ & $48,000,000$ & $37,900,00$ \\
\hline Italy & $31,100,000$ & $77,400,000$ & $123,000,000$ & $32,500,000$ & $45,900,000$ \\
\hline UK & $138,000,000$ & $259,000,000$ & $271,000,000$ & $130,000,000$ & $195,000,000$ \\
\hline Germany & $30,400,000$ & $73,400,000$ & $110,000,000$ & $37,900,000$ & $30,600,000$ \\
\hline Thailand & $20,700,000$ & $35,600,000$ & $52,400,000$ & $19,100,000$ & $24,300,000$ \\
\hline Total & $348,800,000$ & $786,100,000$ & $1,045,100,000$ & $395,500,000$ & $449,500,000$ \\
\hline Filter 2 & \multicolumn{5}{|c|}{ Search or meta-search engine } \\
\hline USA & 11,100 & 14,700 & 29,500 & 17,700 & 16,800 \\
\hline Spain & 12,500 & 11,600 & 24,700 & 17,500 & 13,700 \\
\hline China & 13,600 & 9,730 & 26,200 & 17,000 & 12,600 \\
\hline France & 43,300 & 14,600 & 56,300 & 48,900 & 45,000 \\
\hline Italy & 11,500 & 10,900 & 25,000 & 17,000 & 13,600 \\
\hline UK & 13,000 & 16,200 & 33,100 & 18,200 & 16,300 \\
\hline Germany & 11,800 & 10,900 & 24,700 & 17,500 & 13,500 \\
\hline Thailand & 37,500 & 10,500 & 47,500 & 42,800 & 38,600 \\
\hline Total & 154,300 & 99,130 & 267,000 & 196,600 & 170,100 \\
\hline Filter 3 & B2C webs & & & & \\
\hline Total & 246 & 160 & 426 & 298 & 272 \\
\hline Filter 4 & $\begin{array}{ll}\text { - } & \text { Without } \\
- & \text { Without } \\
\text { - } & \text { Without } \\
\text { - } & \text { Without }\end{array}$ & $\begin{array}{l}\text { duplicate website } \\
\text { different websites } \\
\text { oublic administrat } \\
\text { specific business }\end{array}$ & $\begin{array}{l}\text { epending on co } \\
\text { n websites } \\
\text { ebsites (only se }\end{array}$ & $\begin{array}{l}\text { try or domain } \\
\text { rch or metasear }\end{array}$ & \\
\hline Total & 99 & & & & \\
\hline
\end{tabular}

Trinidad Domínguez Vila Elisa Alén González Nelia Araújo Vila José Antonio Fraiz Brea 


\section{Appendix B: Search and Meta-Search Engines Websites}

\begin{tabular}{|c|c|}
\hline Search and meta-search engines & Websites \\
\hline 9FLATS & http://www.9flats.com/ \\
\hline AFFORDABLE TOURS & http://www.webjet.com/ \\
\hline AGODA & http://www.agoda.com/ \\
\hline AIRBNB & https://www.airbnb.com/ \\
\hline AIRCHINA & http://www.airchina.com/ \\
\hline ASIA ROOMS & http://www.asiarooms.com/ \\
\hline ASIA TRAVEL & http://www.asiatravel.com/ \\
\hline ASIA WEB DIRECT & http://www.asiawebdirect.com/ \\
\hline ATRÁPALO & http://www.atrapalo.com/ \\
\hline BACK YARD TRAVEL & http://www.backyardtravel.com/ \\
\hline BAHN & http://www.bahn.com/ \\
\hline B\&B HOTELS & http://www.hotel-bb.com/ \\
\hline BED AND BREKFAST & http://www.bedandbreakfast.com/ \\
\hline BOOKING & http://www.booking.com \\
\hline CHEAPFLIGHT & http://www.venere.com/ \\
\hline CHEAPOAIR & http://www.cheapoair.com/ \\
\hline CHINA AIRLINE TRAVEL & http://chinaairlinetravel.com/ \\
\hline CHINA DISCOUNT HOTELS & http://www.china-discount-hotels.com/ \\
\hline CHINA EASTERN & http://hk.ceair.com/ \\
\hline CHINA HOTELS RESERVATION & http://www.chinahotelsreservation.com/ \\
\hline CHINA CONNECTION TOURS & http://www.china-tour.com/ \\
\hline CTRIP & http://english.ctrip.com/ \\
\hline DESPEGAR & http://www.us.despegar.com/ \\
\hline DESTINIA & http://destinia.com/ \\
\hline EASY VIAJAR & http://www.easyviajar.com/ \\
\hline EASYJET & http://www.easyjet.com/ \\
\hline EBOOKERS & http://www.ebookers.com/ \\
\hline EDREAMS & http://www.edreams.es/ \\
\hline ELONG & http://www.china-discount-hotels.com/ \\
\hline EMMA VILLAS & http://www.emmavillas.com/ \\
\hline EUROLINES & http://www.eurolines.co.uk/ \\
\hline EVANEOS & http://www.evaneos.com/ \\
\hline EXPEDIA & http://www.expedia.com/ \\
\hline FARE COMPARE & http://www.farecompare.com/ \\
\hline GERMAN TOURIST HOTELS & http://www.germantouristhotels.com/ \\
\hline HIHOSTELS & https://www.hihostels.com/ \\
\hline HIPMUNK & https://www.hipmunk.com/ \\
\hline HOMELIDAYS & http://www.homelidays.com/ \\
\hline HOSTEL BOOKERS & http://www.hostelbookers.com/ \\
\hline HOSTEL WORD & http://www.hostelworld.com/ \\
\hline HOT WIRE & http://www.hotwire.com/ \\
\hline HOTEL BOOK & http://www.hotelbook.com/ \\
\hline HOTEL CLUB & http://www.hotelclub.com/ \\
\hline HOTEL CONBINED & http://www.hotelscombined.com/ \\
\hline HOTEL SEARCH & http://www.hotelsearch.com/ \\
\hline HOTEL THAILAND & http://www.hotelthailand.com/ \\
\hline HOTELS 2 THAILAND & http://www.hotels2thailand.com/ \\
\hline HOTEL TRAVEL & http://www.hoteltravel.com/ \\
\hline HOTEL URBANO & http://www.hotelurbano.com/ \\
\hline HOTELS.COM & http://www.hotels.com/ \\
\hline HRS & http://www.hrs.com/ \\
\hline IBIS BUDGET & http://ibisbudgethotel.ibis.com/ \\
\hline IN ITALIA & http://www.initalia.it/ \\
\hline JETCOST & http://www.jetcost.com/ \\
\hline KAYAK & http://www.kayak.com/ \\
\hline LAST MINUTE & http://www.es.lastminute.com/ \\
\hline LATE ROOMS & http://www.laterooms.com/ \\
\hline LILIGO & http://www.liligo.com/ \\
\hline LOGITRAVEL & http://www.logitravel.com/ \\
\hline
\end{tabular}




\begin{tabular}{|c|c|}
\hline \multicolumn{2}{|c|}{ Table Appendix B: continuation } \\
\hline LOWCOST HOLYDAYS & http://www.lowcostholidays.com/ \\
\hline LUXURY RETREATS & http://www.luxuryretreats.com/ \\
\hline MAKE MY TRIP & http://www.makemytrip.com/ \\
\hline MEJORES VUELOS & http://www.mejores-vuelos.com/ \\
\hline MINUBE & http://www.minube.com/ \\
\hline MOBISSIMO & http://www.mobissimo.com/ \\
\hline MOMONDO & http://www.momondo.com/ \\
\hline MUCHOVIAJE & http://vacaciones.muchoviaje.com/ \\
\hline OMEGA TRAVEL & http://uk.omegatravel.net/ \\
\hline ONETWOTRIP & http://www.onetwotrip.com/ \\
\hline OPODO & http://www.opodo.co.uk/ \\
\hline ORBITZ & http://www.orbitz.com/ \\
\hline PARK INN & http://www.parkinn.com/ \\
\hline PRICE LINE & http://www.priceline.com/ \\
\hline PHUKET & http://www.phuket.com/ \\
\hline QUNAR & http://www.qunar.com/ \\
\hline RAILEUROPE & http://www.raileurope.com/ \\
\hline RATESTOGO & http://www.ratestogo.com/ \\
\hline ROOM 77 & https://www.room77.com/ \\
\hline ROUTEPERFECT & http://www.routeperfect.com/ \\
\hline RUMBO & http://www.rumbo.com/ \\
\hline SAWADEE & http://www.sawadee.com/ \\
\hline SLEEP IN ITALY & http://www.sleepinitaly.com/ \\
\hline SKYSCANNER & http://www.skyscanner.com/ \\
\hline STATRAVEL & http://www.statravel.co.uk/ \\
\hline TRAVEL EUROPE & http://www.traveleurope.com/ \\
\hline TRAVEL JUNGLE & http://www.traveljungle.fr/ \\
\hline TRAVELOCITY & http://www.travelocity.com/ \\
\hline TRAVELSUPERMARKET & http://www.travelsupermarket.com/ \\
\hline TRAVELZOO & http://www.travelzoo.com/ \\
\hline TRIPADVISOR & http://www.tripadvisor.com/ \\
\hline TRIVAGO & http://www.trivago.com/ \\
\hline VENERE & http://www.venere.com/ \\
\hline VIGGIARE & http://www.viaggiare.it/ \\
\hline VOYAGES-SNCF & http://uk.voyages-sncf.com/en/ \\
\hline VUELING & http://www.vueling.com/es/reserva-tu-vuelo/busca-tu-vuelo \\
\hline VUELOS BARATOS & http://www.vuelosbaratos.es/ \\
\hline WEB JET & http://www.webjet.com.au/ \\
\hline WEGO & http://www.wego.com/ \\
\hline WIMDU & http://www.wimdu.es/ \\
\hline WOTIF & http://www.wotif.com/ \\
\hline YOU VUELOS & http://www.youvuelos.com/ \\
\hline ZINGARATE & http://www.zingarate.com/ \\
\hline
\end{tabular}

